\title{
DAMPAK PERTUMBUHAN EKONOMI, SUKU BUNGA, INFLASI, DAN KEBIJAKAN FISKAL TERHADAP INVESTASI DI INDONESIA
}

\author{
Enggal Sriwardiningsih \\ Jurusan Manajemen, Fakultas Ekonomi dan Bisnis, Universitas Bina Nusantara \\ Jln. K.H. Syahdan No. 9, Palmerah, Jakarta Barat 11480 \\ enggalnabeel@yahoo.com
}

\begin{abstract}
Difficulty of finding investment funding has made a nation uses every means to gather them. Sources of investment funding to come from domestic as well as from abroad. Governments should be able to induce foreign investors to be interested in investing in Indonesia, as well as how to make the capital owners in the country to remain willing to make investments in Indonesia so that they do not invest their capital abroad. In this regard, the government must be able to prepare a conducive investment climate in the country (economic growth, interest rates, inflation, and macroeconomic policies in the country) for economic actors to feel safe in their activities. The purpose of this study is to see the impact of domestic capital and foreign capital in investment transactions in Indonesia. The methodology used is regression with time series. The analysis showed that changes in macroeconomic conditions such as growth, interest rates and inflation in some developed countries, including America and European countries in the region does not give a significant influence on Indonesian Foreign Investment, therefore the impact of the severe financial crisis in America and Europe today on Indonesian Foreign Investment is still within limits of tolerance. Therefore, although there are problems in the investment climate in Indonesia, Indonesia's investment prospects over the coming period is still good, though perhaps with slowed investment growth.
\end{abstract}

Keywords: growth, interest rates, inflation, fiscal, investment

\begin{abstract}
ABSTRAK
Sulitnya mencari pendanaan investasi membuat sebuah negara menggunakan segala cara untuk mengumpulkannya. Sumber pendanaan investasi dapat berasal dari dalam negeri maupun dari luar negeri. Pemerintah harus dapat membuat para investor luar negeri tertarik untuk menanamkan modalnya di Indonesia, serta bagaimana membuat para pemilik modal di dalam negeri untuk tetap mau melakukan investasinya di Indonesia sehingga tidak menginvestasikan modal yang dimilikinya di luar negeri. Berkenaan dengan hal tersebut, pemerintah harus mampu menyiapkan iklim investasi yang kondusif di dalam negeri (pertumbuhan ekonomi, tingkat suku bunga, inflasi, dan kebijakan ekonomi makro dalam negeri) agar pelaku ekonomi merasa aman dalam melakukan aktivitasnya. Tujuan penelitian ini adalah ingin melihat pengaruh modal dalam negeri maupun modal luar negeri dalam transaksi investasi di Indonesia. Metodologi yang dipakai adalah regresi dengan time series. Hasil analisis menunjukkan bahwa perubahan kondisi makro ekonomi seperti pertumbuhan, suku bunga dan inflasi di beberapa negara maju, termasuk Amerika dan negara di kawasan Eropa tidak memberi pengaruh signifikan terhadap PMA Indonesia, sehingga krisis finansial parah di kawasan Amerika dan Eropa saat ini, dampaknya terhadap PMA Indonesia masih dalam batas toleransi. Oleh karena itu meski masih terdapat permasalahan-permasalahan dalam iklim investasi di Indonesia, prospek investasi di Indonesia selama kurun waktu mendatang masih tetap baik, meski mungkin dengan pertumbuhan investasi melambat.
\end{abstract}

Kata kunci: pertumbuhan, suku bunga, inflasi, fiskal, investasi 


\section{PENDAHULUAN}

Investasi bersama komponen permintaan agregat lainnya berperan penting tidak hanya dalam pertumbuhan ekonomi, tetapi juga dalam menciptakan lapangan kerja, meningkatkan kapasitas dan kemampuan teknologi, mendorong pembangunan ekonomi kerakyatan. Bahkan lebih jauh dari itu, investasi berperan besar dalam menentukan daya saing produk Indonesia di pasar dalam negeri maupun luar negeri serta dapat mengurangi kemiskinan dan meningkatkan kesejahteraan masyarakat. Permasalahan yang timbul adalah begitu sulitnya negara Indonesia dalam menggalang dana guna investasi di Indonesia. Hal ini menjadi problema yang tidak ringan karena masih banyaknya variabel ekonomi Indonesia yang relatif tidak stabil sebagai ciri dari negara yang sedang berkembang terhadap keputusan investor asing dalam menanamkan modalnya di Indonesia. Di samping itu, adanya fenomena ketertarikan pemilik dana domestik untuk menanamkan modalnya di luar negeri karena dianggap lebih menjanjikan daripada menanamkan modalnya di dalam negeri.

Sumber pendanaan investasi dapat berasal dari dalam negeri maupun luar negeri. Artinya adalah pemerintah harus dapat membuat para investor luar negeri tertarik untuk menanamkan modalnya di Indonesia serta bagaimana membuat para pemilik modal di dalam negeri untuk tetap mau melakukan investasinya di Indonesia sehingga tidak menginvestasikan modal yang dimilikinya di luar negeri. Berkenaan dengan hal tersebut, pemerintah harus mampu menyiapkan iklim investasi yang kondusif di dalam negeri agar pelaku ekonomi merasa aman dalam melakukan aktivitasnya. Berbagai langkah yang telah diupayakan pemerintah dalam rangka perbaikan iklim investasi di Indonesia, di antaranya tercermin dengan diterbitkannya Instruksi Presiden (INPRES) No. 3 tahun 2006 tentang Paket Kebijakan Perbaikan Iklim Investasi pada bulan Februari 2006. Paket ini terdiri dari kebijakan umum, kepabeanan dan cukai, perpajakan, ketenagakerjaan, dan Usaha Kecil, Menengah dan Koperasi (UKMK). Selain itu, pada awal tahun 2006, pemerintah mengeluarkan Paket Kebijakan Infrastruktur untuk meningkatkan investasi di bidang infrastruktur. Pada bulan Juli 2006, Pemerintah dan Bank Indonesia mengeluarkan Paket Kebijakan Sektor Keuangan. Bahkan, secara khusus pemerintah telah mengesahkan UU No. 25 Tahun 2007, tentang Penanaman Modal dan beberapa kebijakan turunannya, yang semua itu dalam rangka mendorong investasi Indonesia.

Namun, disadari pula bahwa krisis keuangan global saat ini yang diikuti kebijakan perbaikan ekonomi di berbagai negara merupakan tantangan yang tidak kecil dalam prospek pengembangan investasi di Indonesia. Sebagai lanjutan dari krisis global tersebut, IMF (World Economic Outlook database) memperkirakan pertumbuhan ekonomi advanced economies akan turun dari $2.7 \%$ di tahun 2007, diestimasikan menjadi 1.0\% di tahun 2008, dan diproyeksikan menjadi -1.8\% di tahun 2009.

Selain itu, berbagai indikator makro ekonomi pada negara-negara pesaing seperti pertumbuhan ekonomi, inflasi, dan suku bunga yang lebih kondusif dibandingkan Indonesia akan mempersulit usaha Indonesia untuk pengembangan investasi. Kondisi iklim investasi di Indonesia dinilai masih memprihatinkan. Hasil survei lembaga internasional, World Economic Forum dalam laporannya yang berjudul "The Global Competitiveness Report 2006- 2007" menyatakan bahwa peringkat Indonesia dalam Global Competitiveness Index sudah meningkat, peringkat ke 50 pada tahun 2006. Peringkat Indonesia pada tahun 2006 ini lebih tinggi dibandingkan dengan Vietnam (peringkat 77), tetapi masih lebih rendah dibandingkan dengan Singapura (peringkat 5), Malaysia (peringkat 26), dan Thailand (peringkat 35). Hal ini menunjukkan seriusnya persoalan iklim investasi di Indonesia.yang harus segera disikapi.

Kaum klasik mengatakan bahwa investasi akan dilakukan apabila pendapatan dari investasi (return of investment) lebih besar dari tingkat suku bunga yang berlaku. Kaum klasik menetapkan patokan tingkat suku bunga sebagai pertimbangan untuk mengadakan investasi. Dalam kondisi ini, dari sudut pandang The General Theory Keynes, maka penganut Keynesian sangat meyakini perlunya 
campur tangan pemerintah untuk mencapai kondisi perekonomian yang lebih baik. Model HarrodDomar mengemukakan secara konkret dan hubungan linier antara investasi dan tingkat pertumbuhan dunia. Melibatkan banyak ahli ekonomi pembangunan (cara yang bukan dimaksud oleh Domar) melakukan peramalan tingkat pertumbuhan GDP dalam pembangunan dunia, dan mengestimasi tingkat bantuan luar negeri sebagai syarat untuk mencapai beberapa target tingkat pertumbuhan. Saat ini perekonomian suatu negara tidak lagi bebas pengaruh dari berbagai kebijakan ekonomi di negara lain. Intinya saat ini interdependensi aktivitas ekonomi antarnegara adalah sebuah keniscayaan. Secara teoritis, interdependensi aktivitas ekonomi suatu negara dengan negara luar diilustrasikan dalam Model Mundell-Flemming. Model analisis ini merupakan penyebaran dari kerangka analisis model Keynes (Mankiw, 2007). Dalam kerangka analisis Mundell-Fleming, Indonesia dapat diilustrasikan sebagai negara kecil yang bersifat terbuka (SOE: Small Open Economy) seperti diperkenalkan oleh Mundell-Fleming (Mankiw, 2007), dengan alasan (1) Perubahan suku bunga di Indonesia tidak mempengaruhi atau pengaruhnya sangat kecil terhadap suku bunga dunia, dan (ii) Sebaliknya, perubahan suku bunga negara-negara besar ataupun bunga internasional pengaruhnya akan langsung mempengaruhi perekonomian Indonesia.

Tujuan penelitian ini adalah ingin melihat pengaruh beberapa variabel ekonomi makro ekonomi (pertumbuhan ekonomi, tingkat suku bunga, inflasi dan kebijakan ekonomi fiskal) dalam penggalangan modal dalam negeri maupun luar negeri dalam transaksi investasi di Indonesia. Metode yang dipakai adalah regresi dengan time series. Selain variabel kondisi dalam negeri juga memperhitungkan perubahan ekonomi luar negeri pertumbuhan, suku bunga dan inflasi di beberapa negara maju, termasuk Amerika dan negara di kawasan Eropa.

Berdasarkan pada uraian sebelumnya, dalam rangka memformulasi kebijakan untuk mendorong minat investor untuk meningkatkan investasinya di Indonesia, maka dirumuskan penelitian ini untuk melihat (1) Dampak pertumbuhan ekonomi (DN), suku bunga (DN), inflasi (DN), dan kebijakan fiskal dalam negeri terhadap investasi di Indonesia; (2) Dampak pertumbuhan ekonomi (LN), suku bunga (LN), inflasi (LN), dan kebijakan fiskal dalam negeri terhadap investasi di Indonesia; (3) Mengidentifikasi negara-negara mana yang dapat dijadikan mitra dalam menarik PMA di Indonesia.

\section{METODE PENELITIAN}

Untuk keperluan analisis investasi di Indonesia ini, maka jenis data yang digunakan adalah data sekunder yang bersifat runtun waktu. Berbagai data yang akan digunakan dikumpulkan dari berbagai instansi terkait seperti Bank Indonesia, BPS, dan instansi lain yang relevan. Secara umum, metode analisis yang digunakan dalam kajian ini adalah model ekonometrika untuk melihat dampak pertumbuhan ekonomi, suku bunga, inflasi, dan kebijakan fiscal terhadap investasi.

Adapun analisis dimaksud berdasarkan pada masing-masing tujuan penelitian. Untuk tujuan pertama, yaitu menganalisis dampak kebijakan pemerintah di bidang ekonomi makro terhadap minat investor untuk berinvestasi di Indonesia, menggunakan metode Model regresi (data time series), di mana kebijakan makro ekonomi dalam negeri dijadikan sebagai dummy variable dengan persamaan sebagai berikut.

$$
\text { Invest }=\beta_{0}+\beta_{1} P E+\beta_{1} \operatorname{Inf}+\beta_{2} S B+\beta_{3} D K M+\varepsilon_{i}
$$

Di mana:

Invest $=$ Investasi dalam negeri (PMDN Rp. Juta)

$P E \quad=$ Pertumbuhan Ekonomi dalam negeri (\%) 


$$
\begin{array}{ll}
\text { Inf } & =\text { Inflasi dalam negeri } \\
\text { SB } & =\text { Suku Bunga Kredit dalam negeri (\% per tahun) } \\
D K M & =\text { Dummy kebijakan makro ekonomi dalam negeri } \\
\varepsilon & =\text { Error }
\end{array}
$$

Tujuan kedua, yaitu menganalisis dampak kebijakan di luar negeri terhadap investasi di Indonesia. Metode analisis juga menggunakan model regresi dengan model persamaan sebagai berikut.

$$
\text { Invest } L N=\beta_{0}+\beta_{1} P E_{L N}+\beta_{2} \operatorname{Inf}_{L N+} \beta_{3} S B_{L N}++\varepsilon_{i}
$$

Di mana :

Invest LN $\quad=$ Investasi Asing di Indonesia (PMA US \$ 000)

$P E_{I N} \quad=$ Pertumbuhan Ekonomi Luar Negeri (\%)

Inf $\quad=$ Inflasi luar negeri

$S B_{I N} \quad=$ Suku Bunga Luar Negeri (\% per tahun)

$\varepsilon \quad=$ Error

HASIL DAN PEMBAHASAN

Ketika perusahaan ingin berinvestasi dalam modal baru, perusahaan membutuhkan sumbersumber pendanaan. Sumber-sumber pendanaan ini bermacam-macam bentuknya, yaitu memperoleh pinjaman dari bank, menjual obligasi kepada publik, atau menjual saham di pasar saham guna mendapatkan laba di masa depan. Cara mendapatkan sumber pendanaan ini disebut dengan model neoklasik. Model ini mengasumsikan bahwa jika perusahaan ingin membayar biaya modal, maka pasar uang akan menyediakan dananya (Mankiw, 2007).

Dalam memperoleh sumber pendanaan, perusahaan kadang menghadapi batasan pendanaan (financing constraints). Bank memiliki peran penting sebagai sumber pendanaan investasi. Mereka bertindak sebagai perantara (intermediaries) antara orang-orang yang ingin menabung dan yang memiliki proyek-proyek investasi menguntungkan, tetapi memerlukan dana. Ketika bank menjadi atau nyaris insolvent, mereka menjadi kurang mampu menjalankan fungsi ini. Solahuddin dan Islam (2008) mengatakan bahwa faktor yang paling dominan mempengaruhi investasi adalah tabungan domestik, pertumbuhan per kapita, dan bantuan (aid).

Sumber pendanaan investasi dapat diperoleh dari para pelaku ekonomi yang terlibat dalam proses kegiatan akumulasi tabungan domestik serta para pemberi bantuan. Mereka adalah pemerintah, perusahaan swasta, rumah tangga, lembaga keuangan, dan negara donor. Berbagai faktor ekonomi internal yang mempengaruhi penanaman modal dalam suatu perekonomi di antaranya adalah permintaan masyarakat yang dapat tercermin dari pendapatan nasional, suku bunga, inflasi, ketersediaan tenaga kerja dan tingkat upahnya, dan ketersediaan sumber daya lainnya serta sejumlah faktor sosial dan politik seperti kebijakan-kebijakan pemerintah yang berkaitan dengan iklim investasi. 
Tabel 1 Hasil Regresi Dampak Kebijakan Fiskal terhadap Investasi menurut PMDN dan PMA

\begin{tabular}{|c|c|c|c|c|c|c|c|}
\hline \multirow[b]{2}{*}{ No. } & \multirow{2}{*}{$\begin{array}{c}\text { Jenis } \\
\text { Investasi }\end{array}$} & \multicolumn{4}{|c|}{ Koefisen Regresi/P-Value } & \multirow[b]{2}{*}{ R-Squared } & \multirow{2}{*}{$\begin{array}{l}\text { Durbin- } \\
\text { Watson }\end{array}$} \\
\hline & & $\begin{array}{l}\text { Pertumbuhan } \\
\text { Ekonomi }\end{array}$ & Suku Bunga & Inflasi & $\begin{array}{l}\text { Dummy } \\
\text { K.D.Fiskal }\end{array}$ & & \\
\hline 1 & PMDN & $\begin{array}{c}270.74 \\
(0.6820)\end{array}$ & $\begin{array}{l}-1.945 .2 \\
(0.0653)\end{array}$ & $\begin{array}{r}77.00 \\
(0.7018)\end{array}$ & $\begin{array}{r}4.648 .38 \\
(0.220\end{array}$ & 0.4350 & 2. 1899 \\
\hline 2 & PMA & $\begin{array}{l}4.176 .81 \\
(0.0677)\end{array}$ & $\begin{array}{c}-9.106 .50 \\
(0.0192)\end{array}$ & $\begin{array}{l}1.434 .07 \\
(0.0612)\end{array}$ & $\begin{array}{r}37.380 .79 \\
(0.011\end{array}$ & 0.7973 & 1. 4402 \\
\hline
\end{tabular}

Keterangan: $(\ldots)=$ P-Value

Sumber: BKPM, Bank Indonesia, BPS, diolah, 2008

Secara umum, kebijakan fiskal di Indonesia memberi dampak signifikan terhadap peningkatan Investasi di Indonesia, terutama pada kegiatan PMA; sedangkan kegiatan PMDN, pengaruh kebijakan ini tidak nyata. Hanya variabel suku bunga dalam model yang signifikan mempengaruhi investasi PMDN. Hasil ini mengisyaratkan bahwa suku bunga yang tinggi selama ini tampaknya menjadi hambatan kegiatan PMDN di Indonesia, di samping hambatan administratif lainnya bagi masyarakat dalam mengakses permodalan. Sementara itu, faktor determinan dari kegiatan PMA lebih beragam; tidak hanya suku bunga, tapi juga pertumbuhan ekonomi dan inflasi berpengaruh secara signifikan. Hasil regresi dampak kebijakan desentralisasi fiskal terhadap investasi PMDN di Indonesia serta variabel pertumbuhan ekonomi, inflasi, dan kebijakan fiskal tidaklah signifikan. Sementara itu, variabel suku bunga menunjukkan pengaruh negatif yang signifikan dengan nilai P-Value sebesar 0.065. Artinya bahwa semakin rendah tingkat suku bunga, maka investasi PMDN semakin meningkat di Indonesia.

Untuk investasi PMA, menunjukkan bahwa dampak kebijakan fiskal terhadap investasi PMA di Indonesia berpengaruh positif secara signifikan dengan nilai P-Value sebesar 0.011. Variabel Pertumbuhan ekonomi juga berpengaruh positif dengan nilai P-Value sebesar 0.067 yang berarti bahwa peningkatan Pertumbuhan ekonomi yang besar mendorong peningkatan investasi asing. Begitu pula dengan inflasi yang tinggi berpengaruh positif dan nyata terhadap investasi PMA, sedangkan tingkat suku bunga kredit berkorelasi negatif dengan investasi PMA di Indonesia. Artinya bahwa semakin rendah tingkat suku bunga kredit mendorong peningkatan investasi di Indonesia dengan nilai P-Value sebesar 0.019.

Tabel 2 Sumber-sumber Pendanaan Investasi di Indonesia Tahun 2001 - 2006 (dalam persen)

\begin{tabular}{|c|c|c|c|c|c|c|c|}
\hline \multirow{2}{*}{ No. } & \multirow{2}{*}{ Sumber Pendanaan } & \multicolumn{6}{|c|}{ Tahun } \\
\hline & & 2001 & 2002 & 2003 & 2004 & 2005 & 2006 \\
\hline 1 & $\begin{array}{l}\text { Lembaga Non } \\
\text { Keuangan }\end{array}$ & 91.47 & 88.60 & 90.34 & 85.74 & 92.37 & 90.30 \\
\hline $\begin{array}{l}2 \\
3\end{array}$ & $\begin{array}{l}\text { Lembaga Keuangan } \\
\text { Luar Negeri }\end{array}$ & $\begin{array}{l}1.47 \\
7.06\end{array}$ & $\begin{array}{r}0.78 \\
10.62\end{array}$ & $\begin{array}{l}2.15 \\
7.51\end{array}$ & $\begin{array}{r}0.57 \\
13.69\end{array}$ & $\begin{array}{l}0.75 \\
6.88\end{array}$ & $\begin{array}{l}0.52 \\
9.18\end{array}$ \\
\hline
\end{tabular}

Sumber: Neraca Arus Dana Indonesia 2001-2006, BPS data diolah

Dari ketiga sumber pendanaan investasi tersebut, lembaga non keuangan menjadi tulang punggung sumber pendanaan investasi di Indonesia. Rata-rata per tahunnya kontribusi lembaga non keuangan dalam membiayai investasi hampir mendekati 90\%. Selama tahun 2001 sampai 2006, lembaga keuangan hanya memberikan kontribusi yang sangat kecil bagi pendanaan investasi di Indonesia. Sumber pendanaan investasi dari luar negeri memiliki kontribusi yang lebih baik jika dibandingkan dengan sumber dari lembaga keuangan, meskipun persentasenya masih jauh jika dibandingkan dengan sumber dari lembaga non keuangan. 
Menarik untuk disimak dari data yang ditampilkan pada Tabel 2, terlihat bahwa kontribusi lembaga perbankan terhadap pendanaan investasi ternyata sangatlah kecil. Padahal suatu lembaga perbankan didirikan dengan tujuan sebagai perantara (intermediaries) antara orang-orang yang ingin menabung dan yang memiliki proyek-proyek investasi yang menguntungkan, tetapi memerlukan dana.

Kondisi ini menunjukkan bahwa ada sesuatu yang salah terjadi pada lembaga perbankan kita, berkaitan dengan penyaluran dana perbankan untuk kegiatan investasi. Ada 3 kemungkinan yang terjadi, yaitu (1) Ada keterbatasan kemampuan bank dalam menghimpun dana dari masyarakat sehingga total persentase sumber pendanaan investasi yang berasal dari perbankan menjadi sangat terbatas; (2) Perbankan bersikap hati-hati dan agak kurang percaya menyalurkan dana yang dimilikinya kepada para investor, dengan jalan membuat persyaratan aturan perbankan yang dapat dianggap menyulitkan para investor untuk memanfaatkan dana perbankan bagi kegiatan investasi; dan (3) Pihak perbankan telah secara optimal menawarkan sumber pendanaan yang dimilikinya untuk kegiatan investasi, tetapi insentif yang dikenakan kepada investor seperti penetapan bunga bank yang terlalu tinggi. Apabila kemungkinan kedua dan ketiga yang terjadi, maka pemerintah perlu menetapkan kebijakan moneter maupun fiskal agar dapat mendorong iklim investasi menjadi lebih kondusif seperti penurunan suku bunga bank, pemberian insentif, dan disinsentif bagi lembaga perbankan dan para investor yang mau menyalurkan dan memanfaatkan dana perbankan untuk kegiatan investasi.

Sumber pendanaan investasi yang berasal dari luar negeri persentasenya juga rendah, meskipun masih lebih tinggi dari sektor perbankan. Kondisi ini menunjukkan kepada kita bahwa investor dari luar negeri kurang berminat menanamkan investasinya di Indonesia. Hal ini dimungkinkan dengan adanya iklim investasi di Indonesia kondisinya kurang kondusif seperti berbelitnya prosedur perijinan, banyaknya pungutan dan kurangnya transparansi biaya perijinan, rendahnya pelayanan publik serta kurangnya kepastian hukum. Berkenaan dengan hal tersebut, agar para investor luar negeri mau menanamkan investasinya di Indonesia, pemerintah perlu untuk menciptakan iklim bisnis dan investasi yang sehat, dengan jalan melakukan reformasi pelayanan investasi seperti penyederhanaan sistem perijinan, penurunan berbagai pungutan yang tumpang tindih, dan melakukan transparansi biaya perijinan. Tidak kalah pentingnya untuk dilakukan pemerintah, dalam rangka menciptakan iklim usaha dan investasi yang kondusif, pemerintah perlu melakukan koordinasi berbagai peraturan pusat dan daerah yang berkaitan dengan kegiatan usaha dan investasi agar dapat selaras. Sumber pendanaan investasi dari PMA pada dasarnya adalah pendanaan investasi yang bersal dari penanaman investasi langsung oleh perusahaan asing ke Indonesia. Bentuk investasinya dapat berupa pendirian perusahaan-perusahaan asing seperti Multi National Corporation (MNC). Besarnya nilai investasi dari PMA dapat dilihat pada Tabel 3 berikut.

Tabel 3 Sumber Pendanaan Investasi dari Luar Negeri

Tahun 2002 - 2007 (dalam juta Dollar)

\begin{tabular}{llcccccc}
\hline \multirow{2}{*}{ No. Lokasi } & & \multicolumn{7}{c}{ Tahun } \\
\cline { 3 - 8 } & & $\mathbf{2 0 0 2}$ & $\mathbf{2 0 0 3}$ & $\mathbf{2 0 0 4}$ & $\mathbf{2 0 0 5}$ & $\mathbf{2 0 0 6}$ & $\mathbf{2 0 0 7}$ \\
\hline 1 & Asia & 872.9 & $1,482.0$ & $2,334.9$ & $4,309.5$ & $2,678.7$ & $5,133.6$ \\
2 & Eropa & 973.8 & $1,067.80$ & 933.8 & $2,363.3$ & 895.8 & $1,926.3$ \\
3 & Amerika & 67.7 & 155.6 & 208.5 & 148.8 & 153.3 & 132.5 \\
4 & Australia & 86.3 & 6.2 & 208.8 & 44.8 & 9 & 190.2 \\
5 & Afrika & 123.3 & $1,828.20$ & 457.2 & 944.1 & 700 & 208.1 \\
6 & Gabungan Negara & 987.2 & 910.8 & 459.1 & $1,104.1$ & $1,540.2$ & $1,30.9$ \\
\hline
\end{tabular}

Sumber: Bank Indonesia, (2007), data diolah 
Dari sumber pendanaan investasi yang berasal dari luar negeri, apabila dilihat dari peringkat menurut negara sebagai penanam modal terbesar di Indonesia dalam bentuk PMA dapat dilihat pada Tabel 4 berikut.

Tabel 4 Sumber Pendanaan Investasi dari Luar Negeri menurut Peringkat Lima Besar Negara Tahun 2007 (dalam miliar Dollar)

\begin{tabular}{ccccccc}
\hline \multirow{2}{*}{ No. } & \multirow{2}{*}{ Tahun } & \multicolumn{5}{c}{ Lima Besar Peringkat Negara } \\
\cline { 3 - 7 } & & Singapura & Inggris & Jepang & Taiwan & Korsel \\
\hline 1 & 2007 & $3,453.60$ & $1,669.20$ & 562.1 & 466 & 270 \\
\hline
\end{tabular}

Sumber: Bank Indonesia, (2007), data diolah

Dari tabel tersebut, terlihat bahwa peringkat negara yang menanamkan investasinya di Indonesia secara langsung melalui PMA adalah Singapura, Inggris, Jepang, Taiwan, dan Korea Selatan. Data tersebut menunjukkan bahwa nilai investasi dari PMA di Indonesia jumlahnya masih sangat terbatas. Kondisi tersebut dapat memberikan gambaran kepada kita bahwa sebenarnya Indonesia perlu lebih meningkatkan hubungan bilateral ke berbagai negara sahabat agar mereka mau lebih meningkatkan penanaman modal yang dimilikinya dalam bentuk PMA di Indonesia.

\section{Dampak Kebijakan Luar Negeri terhadap Pertumbuhan Investasi di Indonesia}

Kinerja investasi merupakan determinan yang sangat menentukan, walaupun tidak secara instan sebagai sumber pertumbuhan ekonomi secara berkesinambungan dari suatu negara, tergantung dari jenis investasinya. Pada sektor-sektor padat karya seperti pertanian, industri kecil, industri manufaktur, dan lain lain, investasi akan banyak dapat menyerap tenaga kerja, menekan pengangguran, dan akhirnya meningkatkan pendapatan (disertai efek penggandanya) akan meningkatkan pendapatan nasional dalam jangka pendek. Sementara itu, pada jenis investasi di bidang peningkatan Sumber Daya Manusia atau SDM (seperti pendidikan) maupun R \& D, dalam jangka pendek tidak bisa diharapkan pada peningkatan pertumbuhan ekonomi.

Tabel 5 Pertumbuhan PMA dan PMDN di Indonesia

\begin{tabular}{ccc}
\hline \multirow{2}{*}{ TAHUN } & \multicolumn{2}{c}{ Pertumbuhan Investasi $(\%$ per tahun) } \\
\cline { 2 - 3 } & PMDN & PMA \\
\hline 2003 & $(2.07)$ & 38.83 \\
2004 & 20.52 & $(13.59)$ \\
2005 & 49.85 & 52.71 \\
2006 & $(48.79)$ & $(58.64)$ \\
2007 & 40.80 & 41.93 \\
Rata-rata & 12.06 & 12.25 \\
\hline
\end{tabular}

Sumber: BKPM 2003-2007 dan BPS

Sinyalemen tentang rendahnya iklim investasi ini cukup dirasakan oleh Pemerintah Indonesia. Trend pertumbuhan investasinya terus menurun. Pada Tabel 6, data pertumbuhan PMDN dan PMA disajikan trend pertumbuhan tersebut. Secara rata-rata, PMDN dan PMA meningkat masing-masing 12.06\%, 12,25\%, dan 6.68\%, tetapi trend tersebut menurun dari tahun 2003 sampai 2007 terutama untuk PMA. Bila fenomena tersebut dikaitkan dengan krisis keuangan global yang mendera perekonomian dunia, maka makin memperbesar pesimisme tersebut, kecuali jika kita terus berusaha untuk mengambil langkah-langkah kebijakan strategis untuk menarik investasi asing (PMA) yang diharapkan menjadi triger bagi perkembangan PMDN. 
Indonesia hanyalah perekonomian kecil yang bersifat terbuka (SOE: Small Open Economy) tidak bisa lepas dari pengaruh kebijakan dari luar negeri, terutama sekali yang mempunyai hubungan dagang. Segala bentuk kebijakan negara mitra seperti penargetan pertumbuhan, penargetan inflasi, penurunan suku bunga maupun berbagai kebijakan yang menyangkut investasi pada negara-negara mitra dagang akan berdampak pada kinerja dan iklim investasi di Indonesia. Keadaannya bisa akan menjadi lebih buruk lagi bila negara-negara mitra dagang tersebut juga merupakan negara pesaing dalam menarik modal asing seperti Malaysia, Thailand, Filipina, China, dan sebagainya.

\section{Negara-negara Mitra dan Pesaing Investasi}

Variabel investasi mempunyai peran sentral untuk suatu pertumbuhan ekonomi suatu negara. Bagi negara-negara maju, fase perkembangan perekonomian umumnya telah menuju atau mencapai mass consumption, di mana aset-aset kapital (surplus ekonomi yang mereka capai selama berabadabad) sudah demikian besar. Dalam posisi seperti itu, negara-negara industri maju umumnya juga ditandai oleh pencarian tempat-tempat investasi ke negara-negara berkembang atau tempat yang umumnya banyak tersedia berbagai sumber daya (terutama sumber daya alam dan sumber daya manusia) yang relatif jauh lebih murah dibandingkan dengan di negara-negara maju. Sumber daya yang banyak mereka miliki terutama adalah kapital dan teknologi, yang perlu diinvestasikan ke negara-negara berkembang, sekaligus untuk mencari perluasan pasar. Oleh karena itu, kajian ini difokuskan pada kebijakan makro yang dipandang paling penting dalam mempengaruhi Indonesia sebagai SOE (Small Open Economy) yakni kebijakan tentang suku bunga, target inflasi, dan pertumbuhan. Adapun sistematika kajian ini dibagi menurut kelompok negara.

Tabel 6 Dampak Kebijakan Makro Ekonomi Negara Maju terhadap PMA Indonesia

\begin{tabular}{|c|c|c|c|c|c|c|}
\hline \multirow[b]{2}{*}{ No. } & \multirow[b]{2}{*}{ Jenis Investasi } & \multicolumn{3}{|c|}{ Koefisen Regresi } & \multirow[b]{2}{*}{ R-Squared } & \multirow[b]{2}{*}{$\begin{array}{l}\text { Durbin- } \\
\text { Watson }\end{array}$} \\
\hline & & $\begin{array}{c}\text { PE Negara } \\
\text { Maju }\end{array}$ & $\begin{array}{c}\text { Inflasi } \\
\text { Negara Maju }\end{array}$ & $\begin{array}{l}\text { Suku Bunga } \\
\text { Negara Maju }\end{array}$ & & \\
\hline 1 & Amerika Serikat (USA) & $\begin{array}{r}92,005 \\
(0.8936)\end{array}$ & $\begin{array}{l}1,210,20 \\
(0.3902)\end{array}$ & $\begin{array}{r}780,305 \\
(0.1669)\end{array}$ & 0.3721 & 1.8846 \\
\hline 2 & Jepang & $\begin{array}{r}570,600 \\
(0.2971)\end{array}$ & $\begin{array}{l}-1,24,10 \\
(0.2732)\end{array}$ & $\begin{array}{r}880,730 \\
(0.6355)\end{array}$ & 0.2600 & 1.4348 \\
\hline 3 & Jerman & $\begin{array}{l}1,026,20 \\
(0.2055)\end{array}$ & $\begin{array}{r}573,500 \\
(0.7211)\end{array}$ & $\begin{array}{r}-970,760 \\
(0.1983)\end{array}$ & 0.2490 & 2.3454 \\
\hline 4 & Itali & $\begin{array}{r}1,154,500 \\
(0.1465)\end{array}$ & $\begin{array}{r}447,530 \\
(0.6232)\end{array}$ & $\begin{array}{r}-686,600 \\
(0.0687)\end{array}$ & 0.4280 & 2.2548 \\
\hline 5 & Kanada & $\begin{array}{r}1,047,740 \\
(0.0526) \\
\end{array}$ & $\begin{array}{r}2,329,470 \\
(0.0247) \\
\end{array}$ & $\begin{array}{r}570,400 \\
(0.2200)\end{array}$ & 0.5410 & 1.4760 \\
\hline
\end{tabular}

Sumber: Diolah dari Laporan Tahun Bank Indonesia, 1998, 2002, dan 2007

Tabel 6 juga menunjukkan secara terperinci pengaruh kebijakan ekonomi makro masingmasing negara maju, di mana terlihat bahwa pertumbuhan ekonomi di semua negara maju ini berkorelasi positif dengan PMA Indonesia, terutama negara dari kawasan Eropa seperti Jerman, Italia, dan Kanada. Gambaran ini menunjukkan bahwa kondisi ekonomi global yang kondusif merupakan faktor penting bagi PMA Indonesia.

Selanjutnya, inflasi di semua negara maju ini juga menunjukkan hubungan positif dengan PMA Indonesia, kecuali inflasi di Jepang yang memiliki korelasi negatif. Hal ini disebabkan karena di Jepang dalam kurun waktu 13 tahun terakhir justru terjadi deflasi, yang ditandai oleh rata-rata inflasi dalam kurun waktu 199-200 mengalami pertumbuhan rata-rata secara negatif. Selanjutnya, dari suku bunga, tampaknya hanya suku bunga dari kawasan Eropa yang memiliki pengaruh nyata dengan korelasi negatif dengan PMA Indonesia. 


\section{Pertumbuhan Ekonomi Negara Industri Maju (NIM) dan Dampaknya terhadap Pertumbuhan PMA}

Kelompok Negara Industri Maju (NIM), nampaknya perlambatan ini akan terus terjadi di tahun 2008, sehubungan dengan krisis finansial yang melanda negeri ini. Situasi ini tentu kurang menggembirakan bagi harapan peningkatan PMA di Indonesia dan berarti Indonesia harus mengelola ataupun memfasilitasi secara lebih baik lagi agar para investor dari USA ini tetap bisa bertahan dan tidak relokasi investasinya ke luar Indonesia.

Secara umum, dampak pertumbuhan GDP negara-negara industri maju terhadap pertumbuhan PMA di Indonesia memiliki hubungan yang searah, di mana ketika pertumbuhan ekonomi negaranegara maju ini mengalami trend peningkatan, maka PMA di Indonesia juga mengalami peningkatan, demikian pula sebalikya. Dalam kajian ini, kelompok negara industri maju yang dipilih adalah Amerika Serikat, Jepang, Jerman, Italia, dan Kanada.

\section{Suku Bunga Negara Industri Maju (NIM) dan Dampaknya terhadap Pertumbuhan PMA}

Data suku bunga juga merupakan muara dari kebijakan ekonomi, khususnya moneter dari suatu negara. Suku bunga merupakan ukuran tingkat upah kapital yang secara langsung mudah diketahui oleh setiap pelaku ekonomi. Suku bunga yang tinggi merupakan disinsentif bagi para investor di sektor riil, dan sebaliknya merupakan insentif yang baik bagi investor di sektor keuangan.

Oleh karena itu, pergerakan suku bunga setiap negara penting untuk dicermati bagi kepentingan penggalangan PMA. Dalam konteks ini, secara khusus selisih antara suku bunga negara industri maju dengan suku bunga Indonesia seringkali sangat menjadi insentif bagi masuknya modal asing. Bila suku bunga asing turun, sementara SBI tetap, maka secara otomatis menjadi peningkatan risk premium sehingga bisa menjadi insentif bagi capital inflow. Namun, di sisi lain kurs Rupiah akan menguat sehingga barang-barang buatan kita menjadi tidak kompetitif. Dengan demikian, dalam konteks investasi, telaah perilaku terhadap suku bunga asing begitu penting.

Dampak suku bunga negara maju terhadap PMA Indonesia menunjukkan bahwa meski perilakunya tidak konsisten untuk semua negara maju, ada kecenderungan bahwa penurunan suku bunga di negara maju dikuti oleh penurunan PMA di Indonesia. Sebaliknya, peningkatan suku bunga di negara tersebut juga diikuti oleh peningkatan PMA Indonesia. Dengan kata lain, ada kecenderungan suku bunga negara maju berkorelasi positif dengan PMA Indonesia.

\section{Inflasi Negara Industri Maju (NIM) dan Dampaknya terhadap Pertumbuhan PMA}

Inflasi merupakan ukuran tingkat kenaikan harga-harga umum di suatu negara. Inflasi yang terjadi di suatu negara juga merupakan hasil dari berbagai kebijakan yang dipilih oleh setiap negara. Pilihan itu berkaitan dengan adanya trade off antara pilihan pertumbuhan ekonomi terhadap tingkat pengangguran. Jadi, menimbang kebijakan pengendalian inflasi dalam kaitannya dengan pertumbuhan ekonomi dan reduksi pengangguran merupakan kebijakan yang erat bertalian satu sama lain. Kecuali itu, kenaikan inflasi mempunyai pengaruh yang berlawanan dengan suku bunga. Inflasi sebenarnya menurunkan nilai kapital. Dalam hal ini, suku bunga nominal dikurangi dengan inflasi merupakan suku bunga riil. Dengan demikian, inflasi yang tinggi merupakan disinsentif bagi investor.

Dampak inflasi dari kenaikan laju inflasi di negara-negara industri maju telah menyebabkan harga-harga-harga barang di dalam negeri mereka meningkat. Peningkatan harga-harga tersebut kemudian menyebabkan investasi di dalam negeri mereka menjadi lebih mahal, yang mendorong para investor untuk meningkatkan investasinya ke negara-negara berkembang, termasuk ke Indonesia, di mana SDA dan SDM nya melimpah. Dengan kata lain, trend peningkatan inflasi di negara maju 
diikuti oleh peningkatan PMA di Indonesia. Dampak inflasi dari negara-negara industri maju terhadap pertumbuhan PMA di Indonesia nampak persesuaian yang baik seperti dapat dilihat pada Gambar 12 . Nampaknya kenaikan laju inflasi di negara-negara industri maju telah menyebabkan harga-hargaharga barang di dalam negeri mereka meningkat. Peningkatan harga-harga tersebut kemudian menyebabkan investasi di dalam negeri mereka menjadi lebih mahal, yang mendorong para investor untuk meningkatkan investasinya ke negara-negara berkembang, termasuk ke Indonesia, di mana SDA dan SDM nya melimpah. Dengan kata lain, trend peningkatan inflasi di negara maju diikuti oleh peningkatan PMA di Indonesia.

\section{Pengujian Dampak Kebijakan Makro Ekonomi Negara Industri Maju (NIM) terhadap PMA Indonesia}

Kebijakan ekonomi negara maju, khususnya kebijakan moneter seperti kebijakan suku bunga dan pengendalian investasi, secara rata-rata tidak berpengaruh signifikan terhadap PMA Indonesia. Namun, ada kecenderungan bahwa jika suku bunga di negara maju ini mengalami peningkatan, maka cenderung berdampak negatif terhadap PMA Indonesia. Gambaran ini menunjukkan bahwa jika suku bunga di negara maju meningkat, para investor dari negara ini cenderung mengurangi investasinya di Indonesia. Bisa jadi perilaku tersebut disebabkan oleh besarnya rate of return dari modalnya lebih besar, jika ditabung di negaranya pada saat suku bunga meningkat ketimbang rate of return dari kegiatan investasi di Indonesia.

Selanjutnya, inflasi di negara maju tidak berpengaruh signifikan terhadap PMA di Indonesia. Namun, ada kecenderungan korelasi yang bersifat positif. Hasil menggambarkan bahwa perilaku investor di negara maju memandang bahwa risiko modal dari tingginya investasi di negaranya dianggap sebagai biaya yang lebih besar dibandingkan kemungkinan risiko berinvestasi di Indonesia. Perilaku seperti ini menyebabkan meningkatnya PMA di Indonesia ketika inflasi di negara maju meningkat. Sementara itu, kondisi perekonomian yang baik yang digambarkan oleh pertumbuhan ekonomi berpengaruh nyata secara positif terhadap PMA Indonesia.

\section{Dampak Kebijakan Ekonomi Negara Industri Baru (NIEs) terhadap PMA Indonesia}

Tabel 7 Dampak Kebijakan Makro Ekonomi Negara Industri Baru (NIEs) terhadap PMA Indonesia

\begin{tabular}{|c|c|c|c|c|c|c|}
\hline \multirow[b]{2}{*}{ No. } & \multirow[b]{2}{*}{ Jenis Investasi } & \multicolumn{3}{|c|}{ Koefisen Regresi } & \multirow[b]{2}{*}{ R-Squared } & \multirow[b]{2}{*}{$\begin{array}{l}\text { Durbin- } \\
\text { Watson }\end{array}$} \\
\hline & & $\begin{array}{l}\text { PE Negara } \\
\text { Industri Baru }\end{array}$ & $\begin{array}{l}\text { Inflasi Negara } \\
\text { Industri Baru }\end{array}$ & $\begin{array}{l}\text { Suku Bunga } \\
\text { Negara Industri } \\
\text { Baru }\end{array}$ & & \\
\hline 1 & Hongkong & $\begin{array}{l}492,200 \\
(0.0221)\end{array}$ & $\begin{array}{l}-274,730 \\
(0.4551)\end{array}$ & $\begin{array}{c}1,520,870 \\
(0.0304)\end{array}$ & 0.8701 & 3.4300 \\
\hline 2 & Korea Selatan & $\begin{array}{l}430,490 \\
(0.4292)\end{array}$ & $\begin{array}{c}-3,301,760 \\
(0.1644)\end{array}$ & $\begin{array}{c}3,996,279 \\
(0.0896)\end{array}$ & 0.7805 & 2.3854 \\
\hline 3 & Singapura & $\begin{array}{l}976,240 \\
(0.0385)\end{array}$ & $\begin{array}{c}3,350,202 \\
(0.0540)\end{array}$ & $\begin{array}{c}1,056,945 \\
(0.2461)\end{array}$ & 0.8310 & 2.7373 \\
\hline 4 & Taiwan & $\begin{array}{l}787,520 \\
(0.0299)\end{array}$ & $\begin{array}{c}1,131,078 \\
(0.2296)\end{array}$ & $\begin{array}{c}3,923,058 \\
(0.0261)\end{array}$ & 0.8210 & 2.4370 \\
\hline
\end{tabular}

Sumber: Diolah dari Laporan Tahunan Bank Indonesia, 1998, 2002, dan 2007

Negara-negara yang tergolong dalam kelompok Negara Industri Baru (NIEs) adalah Korea Selatan, Singapura, Taiwan, dan Hong Kong. Dalam konteks investasi, kelompok NIEs ini mempunyai peran penting, mengingat bahwa (1) NIEs mempunyai surplus kapital serta kekurangan SDA dan SDM, (2) Letaknya yang relatif berdekatan dengan Indonesia sehingga hubungan ekspor 
impor sumber daya dan produk relatif menjadi lebih efisien, (3) Secara kolektif dapat dibangun kerjasama ekonomi secara regional untuk membentuk kekuatan baru di Asia Pasifik. Sehubungan dengan keunggulan-keunggulan ini, maka kajian ini juga dimaksudkan untuk menelaah kebijakan ekonomi dalam kelompok NIEs.

Pada Tabel 7, terlihat bahwa kondisi perekonomian (pertumbuhan ekonomi) di negara-negara industri baru tersebut, yang paling besar pengaruhnya terhadap peningkatan PMA Indonesia adalah Singapura. Demikian pengaruh inflasi negara tersebut juga paling besar di antara negara industri lainnya terhadap PMA Indonesia. Sedangkan variabel suku bunga koefisien regresi paling besar adalah di Korea Selatan. Implikasi dari hasil ini menekankan bahwa untuk meningkatkan PMA Indonesia yang bersumber dari negara-negara industri baru ini, maka Indonesia juga harus berkontribusi dalam menciptakan kondisi perekonomian regional kondusif di kawasan Asia. Selain itu, Indonesia harus menjaga inflasi dan suku bunga tidak terlampau jauh di atas inflasi dan suku bunga di negara-negara industri baru ini.

\section{Pertumbuhan Ekonomi NIEs dan Dampaknya terhadap Pertumbuhan PMA}

Sebagaimana yang terjadi dengan Jepang, Amerika Serikat, dan Eropa, pertumbuhan ekonomi di dalam kelompok NIEs ini kemudian dapat menjadi determinan penting bagi perkembangan PMA di Indonesia. Surplus ekonomi yang dicapai oleh kelompok NIEs nampaknya telah menyebabkan peningkatan PMA di Indonesia. Demikian pula sebaliknya, kontraksi ekonomi pada kelompok NIEs akan menyebabkan kontraksi PMA di Indonesia.

Sehubungan dengan fenomena ini, maka upaya-upaya penggalangan promosi investasi ke negara-negara NIEs haruslah terus dilakukan. Demikian pula dengan perbaikan iklim investasi harus terus ditingkatkan. Dengan cara-cara itu, diharapkan para investor dari NIEs tetap bertahan dan malah meningkatkan realisasi investasinya, walaupun krisis keuangan dunia sedang berlangsung. Fluktuasi suku bunga di NIEs tampaknya cenderung bersesuaian dengan trend fluktuasi PMA di Indonesia. Fenomena ini menunjukkan bahwa kebijakan moneter di berbagai negara industri baru ini sedikit banyaknya dapat berpengaruh terhadap PMA di Indonesia.

\section{Inflasi NIEs dan Dampaknya terhadap Pertumbuhan PMA}

Sebagaimana telah diutarakan dalam pembahasan di kelompok negara industri maju, inflasi bisa menjadi faktor penentu investasi. Inflasi juga merupakan resultansi dari kebijakan penargetan pertumbuhan ekonomi, penurunan tingkat pengangguran, maupun penetapan pilihan kebijakan tingkat suku bunga suatu negara. Inflasi bekerja meningkatkan harga-harga me-negate suku bunga serta menurunkan nilai riil maupun upah kapital.

Oleh karena itu, inflasi yang terjadi di suatu negara akan menjadi penentu minat investasi di negara yang bersangkutan. Dampak laju inflasi dari NIEs terhadap PMA Indonesia memiliki korelasi yang tidak konsisten dengan PMA Indonesia. Pada awal periode, penurunan inflasi di negara tersebut diikuti oleh peningkatan PMA Indonsia, tetapi peningkatan inflasi pada akhir periode juga diikuti oleh peningkatan PMA di Indonesia.

\section{Pengujian Dampak Kebijakan Makro Ekonomi Negara Industri Baru (NIEs) terhadap PMA Indonesia}

Kebijakan makro ekonomi negara-negara industri baru, terutama kebijakan yang mampu menciptakan pertumbuhan ekonomi di negaranya memberi dampak positif terhadap perkembangan PMA di Indonesia. Hal ini ditunjukkan oleh nilai koefisien pertumbuhan ekonomi negara-negara industri baru yang signifikan secara positif terhadap PMA Indonesia. 
Kondisi ini menjelaskan bahwa jika inflasi dan suku bunga di negara-negara industri baru ini rendah atau menurun, maka investor cenderung berinvestasi di negara tersebut, yang kemudian berdampak pada menurunnya minat investasi di Indonesia. Hasil ini memberi pengertian bahwa negara-negara industri maju ini, selain sebagai mitra (terutama Singapura karena lebih 50\% rencana PMA 2007 di Indonesia dari kawasan Asia bersumber dari negara ini), tetapi juga sekaligus sebagai pesaing dalam menarik investasi. Jika iklim investasi di negara tersbut semakin kondusif (yang diindikasikan oleh inflasi dan suku bunga rendah), maka investor di negara tersebut cenderung berinvestasi di negaranya dan mengurangi investasinya di Indonesia.

\section{SIMPULAN}

Berdasarkan investasi penanaman modal asing dan penanaman modal dalam negeri, dapat dilihat bahwa peran investasi belum optimal. Secara umum, berbagai indikator makro ekonomi di Indonesia seperti pertumbuhan ekonomi, suku bunga, dan inflasi memberi dampak signifikan terhadap peningkatan investasi di Indonesia, terutama pada kegiatan penanaman modal asing; sedangkan kegiatan penanaman modal dalam negeri, pengaruh kebijakan ini tidak nyata. Hanya variabel suku bunga dalam model yang signifikan mempengaruhi investasi penanaman modal dalam negeri. Hasil ini mengisyaratkan bahwa suku bunga yang tinggi selama ini tampaknya menjadi hambatan kegiatan penanaman modal dalam negeri di Indonesia, di samping hambatan lainnya seperti perijinan yang rumit dan mahal, ketersediaan infrastruktur yang tidak memadai, khususnya di luar Pulau Jawa, dan lain sebagainya. Kondisi ini merupakan tantangan yang tidak ringan dalam rangka mendorong minat investasi di Indonesia, terutama penanaman modal asing.

\section{DAFTAR PUSTAKA}

Dornbusch, R., Fisher, S., Startz, R. (2008). Makroekonomi, edisi kesepuluh, PT Media Global Edukasi.

Instruksi Presiden (INPRES) No. 3 tahun 2006.

Mankiw, G. (2007). Makroekonomi, edisi keenam, Jakarta: Penerbit Erlangga.

Mankiw, G. (2007). Macroeconomics, $6^{\text {th }}$ ed., New York: Worth Publishers.

Perkembangan Data Ekonomi Makro Indonesia, Biro Pusat Statistik.

Perkembangan Data Ekonomi Makro Negara Mitra Dagang Utama dan Negara Pesaing, World Bank, ADB.

Perkembangan Kebijakan Fiskal di Indonesia tahun 1990 - 2008, Departemen Keuangan.

Realisasi Investasi di Indonesia menurut Sumber Pendanaan Dalam Negeri tahun 1990 - 2008, Bank Indonesia.

Realisasi Investasi di Indonesia menurut Sumber Pendanaan Luar Negeri, Bank Indonesia.

World Economic Forum, The Global Competitiveness Report 2006- 2007, 2008. 